\title{
Production and Optimization of Laccase from Streptomyces lavendulae
}

\author{
Sarvesh Kumar Mishra, Shailendra Kumar Srivastava*, \\ Veeru Prakash, Alok Milton Lall and Sushma
}

\author{
Department of Biochemistry and Biochemical Engineering, JIBB, SHUATS, Allahabad, India \\ *Corresponding author
}

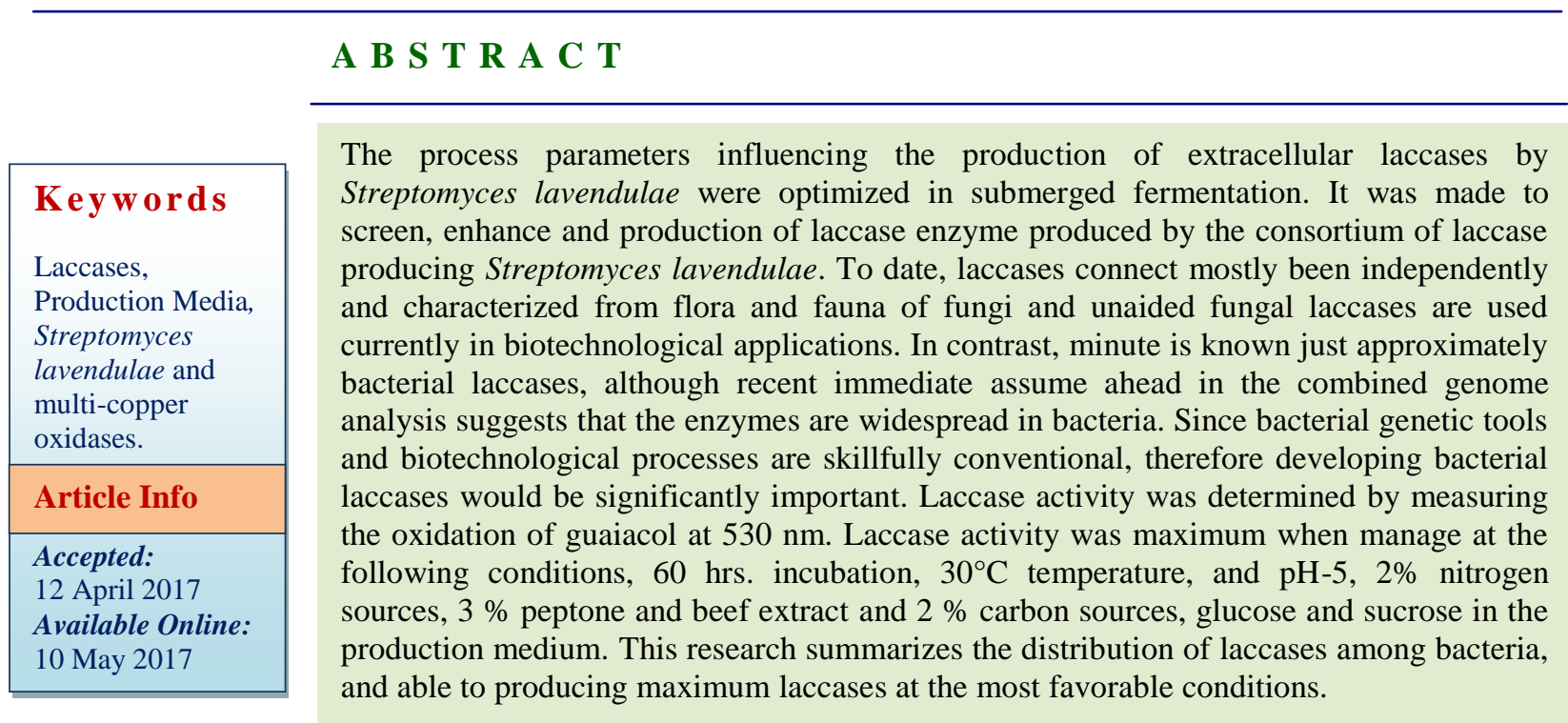

\section{Introduction}

Laccase has wide substrate specificity towards aromatic compounds containing hydroxyl and aminegroups. These enzymes were well-known to catalyze the oxidation of a large range of phenolic compounds and aromaticamines. In fungi, they can be found in ascomycetes, deuteromycetes and most white-rot basidiomycetes (Baldrian, 2006). One of the advantages of laccases is that they reach not require hydrogen peroxide for substrate oxidation and otherwise, they use oxygen as a non-limiting electron acceptor (Michizoe et al., 2005). Laccases are ubiquitous enzymes present in higher plants, bacteria, fungi, insects and lichens (Riva
2006; Lisov et al., 2007). Due to their sophisticated redox potential as compared to the natural world or bacterial laccases, fungal ones are implicated in several biotechnological applications (Brijwani et al., 2010).

Laccases are produced by bacteria, fungi and plant. From the point of view of their structure and function, bacterial and fungal laccases have a similar structure; their amino acid sequences are quite dissimilar. Bacterial laccases frequently occur as monomers, whereas certain fungal laccases take place as isoenzymes that in general oligomerize to 
form multimeric complexes (Claus, 2004; Sakurai, 2007). In recent years, bacterial laccases have gained higher concentration for their potential in biodegrading environmentally significant phenolic pollutants due to their relatively elevated production rate, high thermostability, and broad $\mathrm{pH}$ range, among others (Held, 2005; Hilden, 2009).

Recently some bacterial laccases have also been characterized from Azospirillum lipoforum, Bacillus subtilis, S. cyaneus and Marinomonas mediterranea. A lot of roles for laccases in bacterial systems have been recommended and contain roles in melanin production, spore coat resistance against hydrogen peroxide and UV (Jia et al., 2014).

The application and potential of bacterial laccases for bioremediation applications of bacterial laccases very little are recognized. In generally bacteria tolerate a broader range of habitats and grow faster than fungi (Harms $e t$ al., 2011). Moreover, in contrast to fungal laccases, some bacterial laccases can be highly active and much more stable at high temperatures, at high $\mathrm{pH}$ as well as at high chloride concentrations (Sharma et al., 2007; Bugg et al., 2011; Dwivedi et al., 2011).

The strains Bacillus atrophaeus and Bacillus pumilu produced laccase enzymes can degrade and or modify lignin and contribute to the release of fermentable sugars from lignocellulose (Huang et al., 2013).

Laccase activity was highest when operated at the following conditions, $72 \mathrm{~h}$ incubation, $40^{\circ} \mathrm{C}$ temperature, and $\mathrm{pH}-7,2 \%$ glucose as carbon source and $2 \%$ peptone as the nitrogen source in the manufacturing medium from Pseudomonas aeruginosa (Peter and Vandana, 2014).

\section{Materials and Methods}

\section{Bacterial strain}

Bacterial strain Streptomyces lavendulae MTCC6821was procured from Microbial Type Culture Collection (MTCC) center, Chandigarh, India. The strain was tested for the purity, morphology, and biochemical characteristics. The strains have been tested for laccase producing ability through plate test method. The ability of the bacterial and fungal strains to produce laccase was visualized according to the method of (Kiiskinen et al., 2004).

\section{Measurement of growth}

The growths of bacterial strain was inoculated in nutrient broth and grown at $37^{\circ} \mathrm{C}$ and 180 rpm in an orbital shaker. The strain was subcultured @ 1:100 in $50 \mathrm{ml}$ fresh nutrient broth media in $250 \mathrm{ml}$ Erlenmeyer flasks and grown for $12 \mathrm{hrs}$. Aliquots were withdrawn at hourly intervals and the optical densities were measured using spectrophotometer at $600 \mathrm{~nm}$. The un-inoculated media was used as a blank.

\section{Laccase activity}

The activity of laccase in vivo determined by spectrophotometric tests using phenolic substrates and by monitoring the colored oxidation products. Laccase activity was determined by measuring the oxidation of guaiacol at $530 \mathrm{~nm}$. The reaction mixture was containing $10 \mathrm{mM}$ guaiacol and $100 \mathrm{mM}$ citrate-phosphate buffer (pH5.6).

Absorbance for blank was measured at 470 $\mathrm{nm}$ while that of test samples was measured at $530 \mathrm{~nm}$. Protein concentration was determined by the method of (Lowery et al., 1951) with bovine serum albumin. The following formula was used for determination of enzyme activity. 
Optimization of culture conditions for enzyme production

A range of process parameters that move the enzyme production were optimized greater than a broad range. The entire adopted for standardization of process parameters was to examine the effect of an individual parameter and to incorporate it at the standardized level previously standardizing the neighboring-door parameter. The effects of organic and inorganic nitrogen sources, carbon sources, regulate in the period, temperature, $\mathrm{pH}$, was studied.

\section{Effect of incubation period on enzyme production}

To find out the effect of incubation period on enzyme production, fifty $\mathrm{ml}$ of nutrient broth (NB) culture media was taken in $250 \mathrm{ml}$ Erlenmeyer flasks. The flasks were sterilized, cooled to room temperature, and inoculated with fresh bacterial culture of Streptomyces lavendulae culture was incubated at $120 \mathrm{rpm}$ at different time intervals, namely $24,48,60$, $72,96,120$ and $144 \mathrm{hrs}$. respectively at $30^{\circ} \mathrm{C}$. This culture was used as inoculums for laccase production studies. The contents of the flasks were centrifuged at $10000 \mathrm{rpm}$ for 10 min at $4{ }^{\circ} \mathrm{C}$ and the supernatant was used to assay the enzyme activity at $450 \mathrm{~nm}$. Laccase activity was assayed using the procedure described previously. The sample which is showing high activity considered as $100 \%$ activity.

\section{Effect of temperature on enzyme activity}

Environmental temperature is a factor to which the biomass is an inescapable subject matter since cell temperature should become equal to the temperature of culture medium. The media inoculated with fresh bacterial culture of Streptomyces lavendulae culture was incubated at $120 \mathrm{rpm}$ at different temperature $25,30,35,40,45$, and $50{ }^{\circ} \mathrm{C}$ respectively for $60 \mathrm{hrs}$. This culture was used as inoculums for laccase production studies. The contents of the flasks were centrifuged at $10000 \mathrm{rpm}$ for $10 \mathrm{~min}$ at $4{ }^{\circ} \mathrm{C}$ and the supernatant was used to assay the enzyme activity at $450 \mathrm{~nm}$. The sample which is showing high activity considered as $100 \%$ activity.

\section{Effect of $\mathrm{pH}$ on enzyme activity}

The power of hydrogen ions on biological actions is linked to their hydrogen ion concentration on enzyme activity. The fresh media subculture using the bacterial culture of Streptomyces lavendulae culture and $\mathrm{pH}$ were adjusted in each of the flasks from 4, 4.5, 5, 6, 7 , and 8 (using $\mathrm{HCl}$ or $\mathrm{NaOH}$ ) was incubated at $120 \mathrm{rpm}$ at $30{ }^{\circ} \mathrm{C}$ respectively for $60 \mathrm{hrs}$. The contents of the flasks were centrifuged at $10000 \mathrm{rpm}$ for $10 \mathrm{~min}$ at $4{ }^{\circ} \mathrm{C}$ and the supernatant was used to assay the enzyme activity at $450 \mathrm{~nm}$.

\section{Effect of carbon and nitrogen sources on enzyme activity}

The nature and sum of carbon and nitrogen sources in the culture medium are significant for the growth and construction of laccase by bacterial. The production medium enriched with varying of carbon sources, specifically, glucose, maltose, sucrose, and starch with the final concentrations $(2 \%)$ and varying of inorganic and organic nitrogen sources, specifically, ammonium sulphate, sodium nitrate, peptone and beef extract with the final concentrations $(2 \%) \mathrm{pH}$ was adjusted 5 incubated at $120 \mathrm{rpm}$ at $30^{\circ} \mathrm{C}$ respectively for $60 \mathrm{hrs}$. The contents of the flasks were centrifuged at $10000 \mathrm{rpm}$ for $10 \mathrm{~min}$ at $4{ }^{\circ} \mathrm{C}$ and the supernatant was used to assay the enzyme activity at $450 \mathrm{~nm}$. The sample which is showing high activity considered as $100 \%$ activity. 


\section{Results and Discussion}

Primary screening of the strains became finished through plate assay method. At the strong agar media for isolation, the different isolates might be outstanding through their color and morphology (Fig. 1). The bacterial tradition became investigated for the lignolytic enzyme, laccase pastime with the aid of using guaiacol technique. A easy screening approach was accompanied in organize to hit upon laccase generating bacteria on strong media containing $0.02 \%$ guaiacol as an indicator turned into placed into effect for screening of laccase generating with the aid of bacteria, expand an extreme reddish brown colour in the medium across the bacterial colony vicinity as laccase signs (Ang et al., 2010). The appearance of the reddish brown area inside the medium resulted from the oxidative polymerization of guaiacol (Mabrouk et al., 2010).

The strain Streptomyces lavendulae MTCC6821 that was capable of producing laccase enzymes was selected as the best strain for future works. The growth pattern of Streptomyces lavendulae in nutrient broth is shown in figure 2. The strain Streptomyces lavendulae was growth pattern showed that this strain is not growth defective.

The incubation duration of laccase production indicated that the maximum enzyme yield became performed at $60 \mathrm{hr}$. of incubation. Some of the time, a gradual boom in the enzyme activity was referred to on the starting time of incubation length and the maximum enzyme interest was attained at $60 \mathrm{hr}$ in figure 3.

The most laccase pastime turned into located at $30{ }^{\circ} \mathrm{C}$ at $60 \mathrm{~h}$ of incubation in figure 4 . a few of the temperature, a slow increase in the enzyme activity become referred to on the starting time of incubation period and the maximum enzyme pastime was attained at 30 ${ }^{\circ} \mathrm{C}$ for $60 \mathrm{hrs}$ of incubation in figure 4 . However the manufacturing enzyme hobby was declined on the better incubation temperature of $60^{\circ} \mathrm{C}$ figure 4 .

Fig.1 Bacterial growth on Nutrient agar (NA) and screening of laccase production; A:bacterial culture is stricken on Nutrient agar (NA) incubated at $37{ }^{\circ} \mathrm{C}$ for overnight. B:Using solid media containing $0.02 \%$ guaiacol as indicator compound after 3 days of incubation at $25{ }^{\circ} \mathrm{C}$. The oxidative polymerization of guaiacol to reddish brown zones in the medium by positive strain

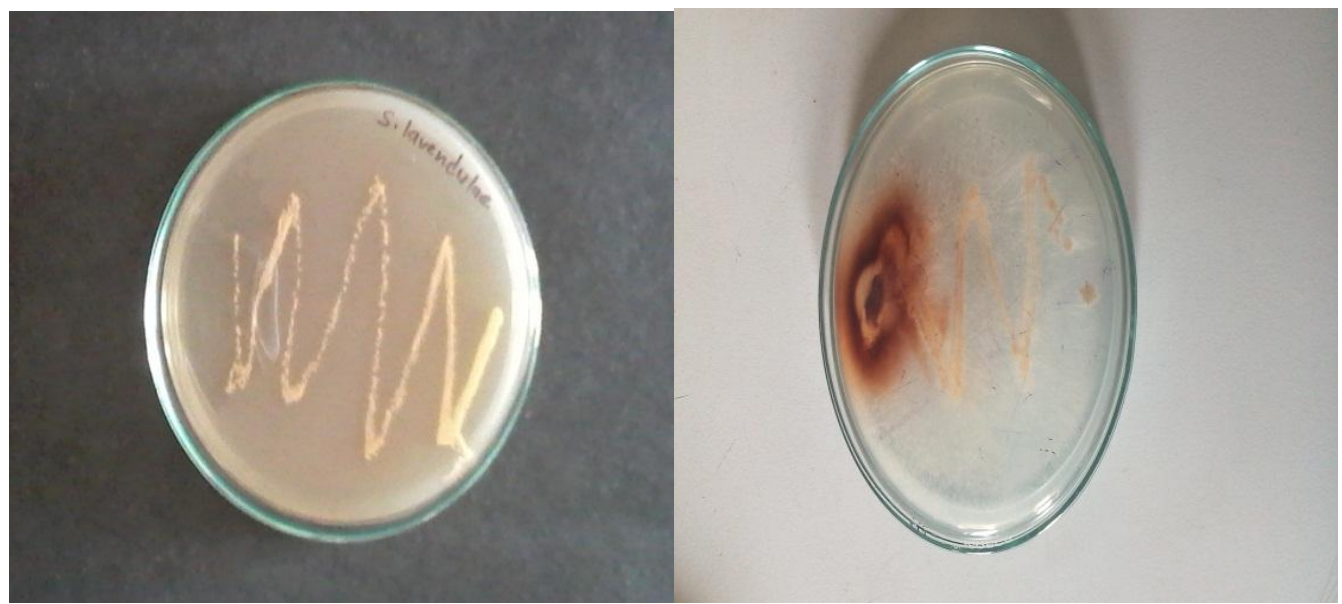

A. Streptomyces lavendulae B. Streptomyces lavendulae 
Fig.2 Bacteria strain does not exhibit defective growth in in-vitro culture media. Streptomyces lavendulae strains were grown in broth media. Aliquots were taken out at one-hour intervals and optical density was measured at $600 \mathrm{~nm}$. Data is presented as mean \pm S.D. $(n=3)$

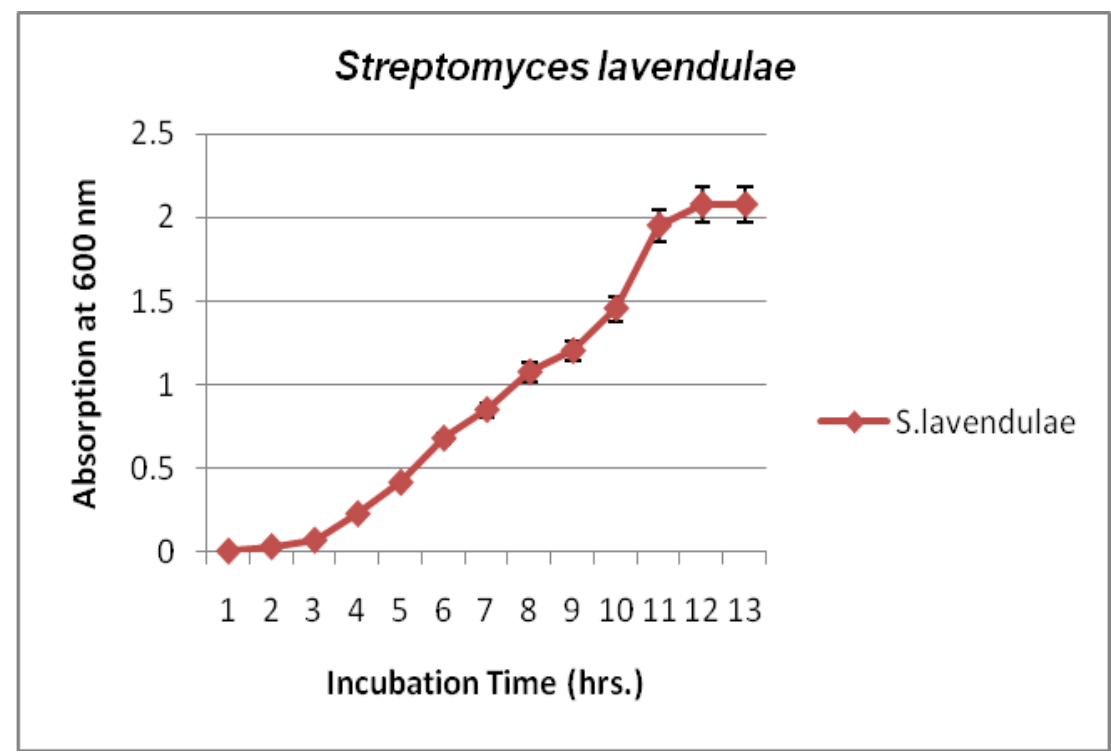

Fig.3 Effect of the incubation period on laccase production. The crude laccase activity from Streptomyces lavendulae using guaiacol oxidation method. Laccase activity was measured using phosphate buffer $(50 \mathrm{mM}, \mathrm{pH} 5.0)$. The error bars in the figure indicate the relative standard deviation

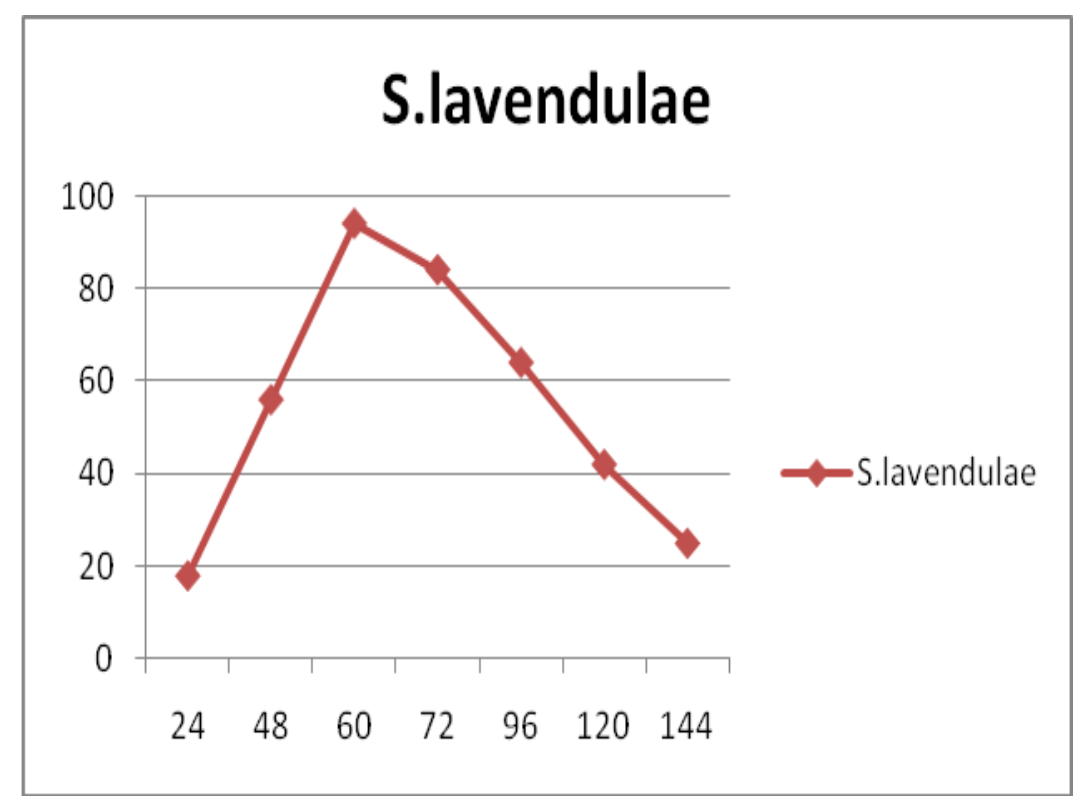


Fig.4 Effect of temperature on laccase production. The crude laccase activity from Streptomyces lavendulae using guaiacol oxidation method. Laccase activity was measured using phosphate buffer $(50 \mathrm{mM}, \mathrm{pH} 5.0)$. The error bars in the figure indicate the relative standard deviation

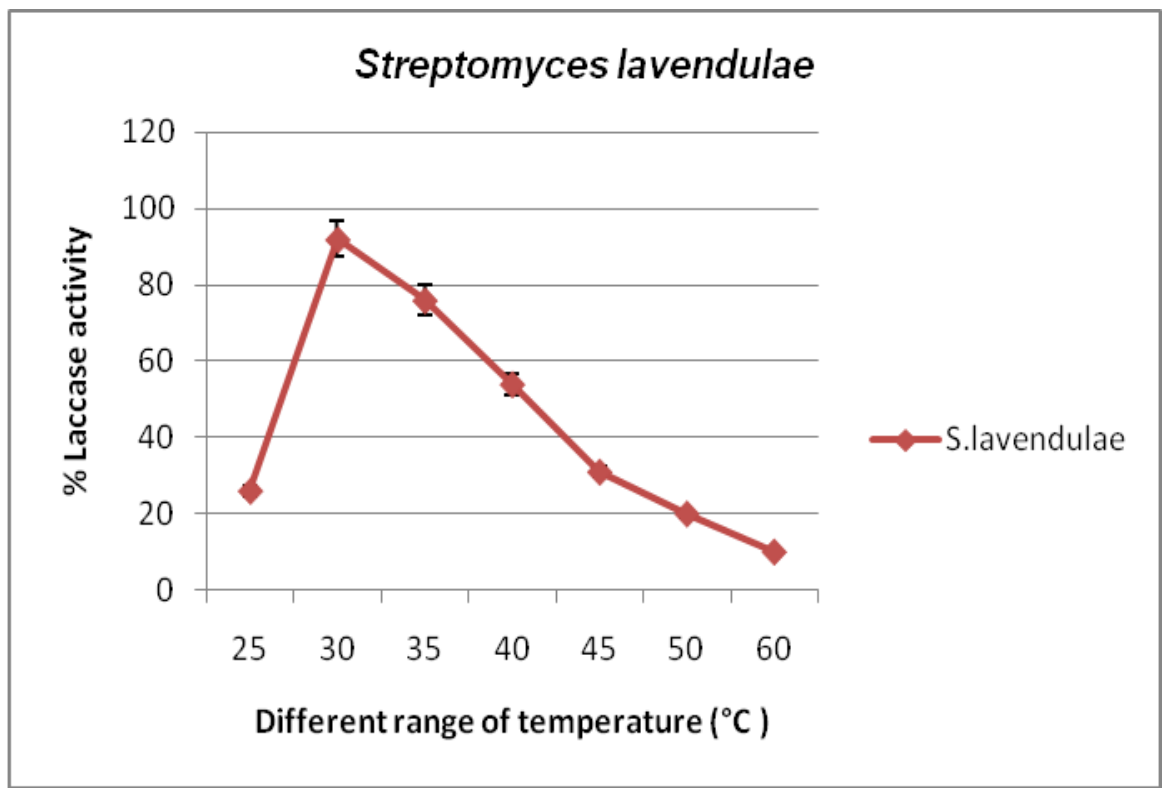

Fig.5 Effect of $\mathrm{pH}$ on laccase production. The crude laccase activity from Streptomyce lavendulae, using guaiacol oxidation method. Laccase activity was measured using phosphate buffer (50mM, pH 5.0). The error bars in the figure indicate the relative standard deviation

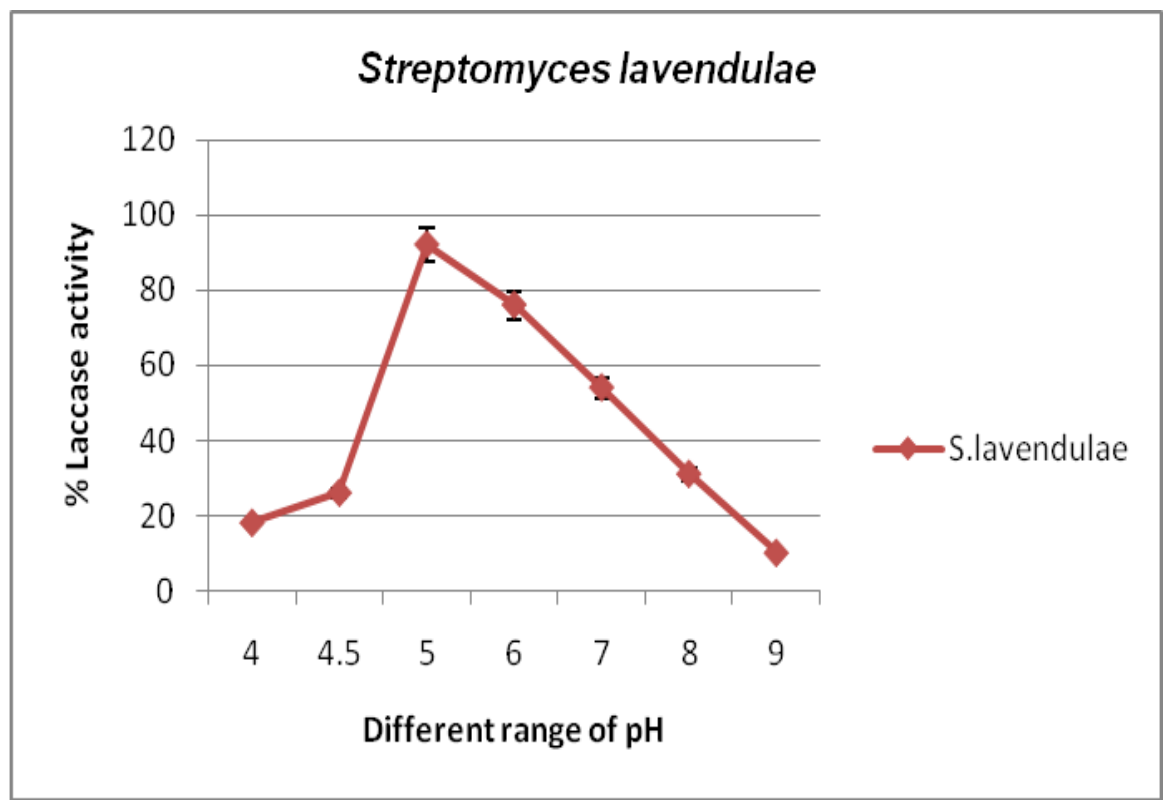


Fig.6 Effect of carbon and nitrogen carbon on laccase production. The crude laccase activity from Streptomyces lavendulae using guaiacol oxidation method. Laccase activity was measured using phosphate buffer $(50 \mathrm{mM}, \mathrm{pH} 5.0)$. The error bars in the figure indicate the relative standard deviation

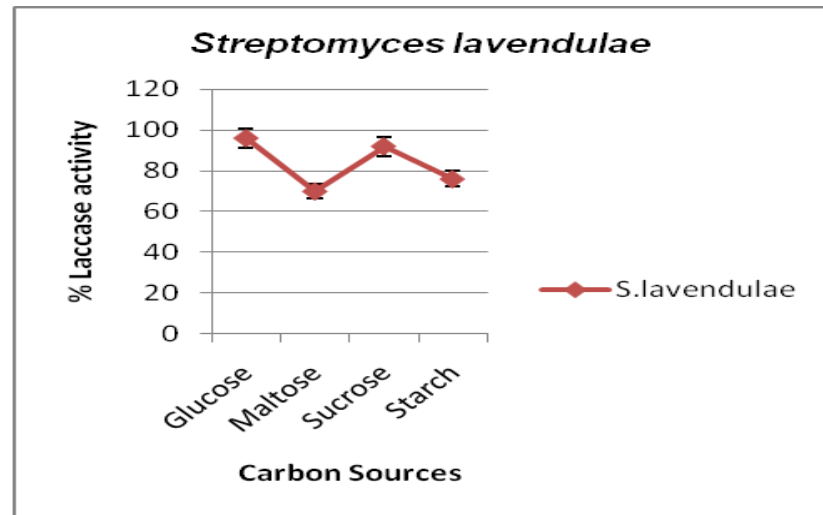

Hydrogen ions concentration $(\mathrm{pH})$ strongly impacts the enzymatic reactions and is receptive to hydrogen ion concentration present in the medium across the cellular membrane (Murugesan et al., 2007). Most laccase activity turned into determined at $\mathrm{pH}$ five for Streptomyces lavendulae, after a period of 3 hrs (Fig. 5).

Nature and sort of carbon and nitrogen are the most vital elements for any fermentation process (Pandey and Radhakrishnan, 1992). In the present observe, complement of the media with special carbon $2 \%$ resources. a few of the carbon assets examined, $2 \%$ glucose and sucrose have been determined to showcase most enzymatic pastime then starch and maltose in figure $6 \mathrm{a}$. Medium containing peptone confirmed the highest laccase hobby as enzymes are substrate precise. Peptone is the simplified source of protein and may be voluntarily uptake by means of the microorganism. a number of the examined nitrogen assets, $2 \%$ peptone and a couple of $\%$ pork extract ended in better laccase manufacturing figure $6 \mathrm{~b}$. Even inside the present study, organic nitrogen assets exhibited most activity as compared to inorganic sources (Fig. 6a). T. villosa laccase showed stepped forward manufacturing the use of peptone (Morozova et al., 2007). In

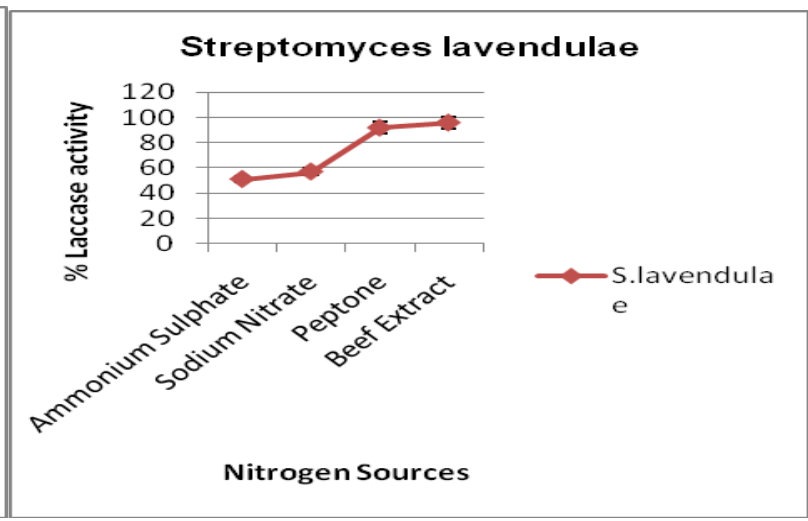

distinction to that, our findings screen that bacterial stress offers maximum laccase pastime with lactose followed by glucose whereas with maltose it does no longer explicit laccase interest.

In conclusion the optimization of cultural and nutritional parameters for the laccase production by using the Streptomyces lavendulae strain in nutrient broth became determined to be a great deal exact than the said values. The boom and high-quality laccase manufacturing of the Streptomyces lavendulae was preferred by using acidic $\mathrm{pH}$ $5,2 \%$ carbon and nitrogen resources at $30{ }^{\circ} \mathrm{C}$ for $60 \mathrm{hrs}$ incubation of the medium.

\section{References}

Ang, T.N., Ngoh, G.C., Chua, A.S.M. 2010. A quantitative method for fungal ligninolytic enzyme screening studies. Asia-Pac. J. Chem. Eng., 451-456.

Baldrian, P. 2006. Fungal laccases occurrence and properties. FEMS Microbiol. Rev., 30: 215-242.

Brijwani, K., Rigdon, A. and Vadlani, P.V. 2010. Fungal laccases: production, function, and applications in food processing. Enzyme Res., 201-210.

Claus, H. 2004. Laccases: structure, reactions, distribution. Micron., 35: 93-96. 
Dwivedi, U., Singh, P., Pandey, V., Kumar, A. 2011. J. Mol. Catal. B-Enzym., 68: 117128.

Harms, H., Schlosser, D. and Wick, L.Y. 2011. Untapped potential: exploiting fungi in bioremediation of hazardous chemicals. Nat. Rev. Microbiol., 9(3): 177-192.

Held, C., Kandelbauer, A., Schroeder, M., Cavaco-Paulo, A. \& Guebitz, G. 2005. Environ. Chem. Lett., 3: 74-77.

Hildén, K., Hakala, T.K. and Lundell, T. 2009. Thermotolerant and thermostable laccases. Biotechnol. Lett., 31(8): pp.11171128.

Huang, X.F., Santhanam, N., Badri, D.V., Hunter, W.J., Manter, D.K., Decker, S.R., Vivanco, J.M. and Reardon, K.F. 2013. Isolation and Characterization of LigninDegrading Bacteria from Rainforest Soils, Biotechnol. Bioeng., 30: 30-40.

Jia, H., Lee, F.S. and Farinas, E.T. 2014. Bacillus subtilis Spore Display of Laccase for Evolution under Extreme Conditions of High Concentrations of Organic Solvent. ACS Combinatorial Sci., 16(12): 665-669.

Kiiskinen, L.L., Kruus, K., Bailey, M., Yl"osm"aki, E., Siika-aho, M., and Saloheimo, M. 2004. "Expression of Melanocarpusal bomyces laccase in Trichoderma reesei and characterization of the purifiedenzyme, Microbiol., 150(9): 3065-3074,.

Lisov, A.V., Zavarzina, A.G., Zavarzin, A.A. and Leontievsky, A.A. 2007. Laccases produced by lichens of the order Peltigerales. FEMS Microbiol. Lett., 275(1): 46-52.

Lowery, O.H., Rosebrough, N.J., Farr, A.L. and Randall, R.J. 1951. The J. Biol. Chem., 193-265.
Mabrouk, A.M., Kheiralla, Z.H., Hamed, E.R. and Youssry, A.A. 2010. Screening of some marine-derived fungal isolates for lignin degrading enzymes. LDEs) production. Agric. Biol. J. N. Am., 1(4): 591-599.

Michizoe, J., Ichinose, H., Kamiya, N., Maruyama, T. and Goto, M. 2005. Biodegradation of phenolic environmental pollutants by a surfactant-laccase complex in organic media. J. Biosci. Bioengi., 99(6):642-647.

Morozova, G.P., Shumakovich, M.A., Gorbacheva, S.V., Shleev and Yaropolov, A.I. 2007. "Blue" laccases," Biochemistry. Moscow), 72(10): 1136-1150.

Murugesan, A., Dhamija, Nam, I.H., Kim, Y.M. and Chang, Y.S. 2007. "Decolourization of reactive black 5 by laccase: optimization by response surface methodology," Dyes and Pigments, 75(1): 176-184.

Pandey, A., \& Radhakrishnan, S. 1992. Packed bed column bioreactor for production of enzymes. Enzyme Microb. Technol., 14: 486-488.

Peter, J.K. and Vandana, P. 2014. Congo red dye decolourization by partially purified laccases from Pseudomonas aeruginosa, Int. J. Curr. Microbiol. App. Sci., 3(9): 105-115.

Riva, S. 2006. Laccases: blue enzymes for green chemistry. Trends Biotechnol., 24: 219- 226.

Sakurai, T. and Kataoka, K. 2007. Basic and applied features of multicopper oxidases, $\mathrm{Cu}_{2} \mathrm{O}$, bilirubin oxidase, and laccase. The Chem. Record, 7(4): 220-229.

Sharma, P., Goel, R. \& Capalash, N. 2007. World J. Microbiol. Biotechnol., 23: 823832.

\section{How to cite this article:}

Sarvesh Kumar Mishra, Shailendra Kumar Srivastava, Veeru Prakash, Alok Milton Lall and Sushma. 2017. Production and Optimization of Laccase from Streptomyces lavendulae. Int.J.Curr.Microbiol.App.Sci. 6(5): 1239-1246. doi: https://doi.org/10.20546/ijcmas.2017.605.134 